\title{
The copper, manganese and zinc content of livers of Impala in the Hoedspruit area
}

\author{
W.A. van Niekerk \\ Dept of Animal and Wildlife Sciences, University of Pretoria, Pretoria 0002. \\ e-mail:wvniekerk@postino.up.ac.za
}

\section{Introduction}

In May 1989, reports were received that a certain number of cattle in the Phalaborwa district had died after showing signs characteristic of a haemolytic crisis, followed by sudden death. Gummow et al. (1991) confirmed this by reporting that chronic copper poisoning in cattle in that area was due to copper air pollution from a nearby copper smelting unit. The objective of this study was to investigate if any differences do occur in the copper, manganese and zinc content of the livers of impala in the Phalaborwa/Hoedspruit area.

\section{Materials and Methods}

Young impala rams, older than 6 months but younger than 2 years, were culled and fresh liver samples were taken. A sample of $\pm 60 \mathrm{~g}$ was taken from the caudate lobe of the liver and stored in $10 \%$ formalin (distilled water used). The area was divided in a northern part (Klaserie, N'tsiri and Ingwelala Game Reserves) and a southern part (Timbavati Game Reserve and Skukuza in the Kruger National Park). The results were also analyzed according to season (dormant and growing season). The minerals were analyzed by a Perkin-Elmer Atomic Absorption Spectrophotometer, Model 2380. The Proc GLM-procedure of SAS (1985) was used to test for differences between localities and seasons.

\section{Results and Discussion}

The $\mathrm{Cu}, \mathrm{Zn}$ and $\mathrm{Mn}$ status of livers of impala are presented in Table 1

Table 1 The $\mathrm{Cu}, \mathrm{Zn}$ and Mn levels in the liver of impala rams in the Hoedspruit area on a DM-basis.

\begin{tabular}{|c|c|c|c|c|c|c|}
\hline \multirow{2}{*}{$\begin{array}{l}\text { Mineral } \\
(\mathrm{mg} / \mathrm{kg})\end{array}$} & \multicolumn{2}{|c|}{ Area } & \multicolumn{3}{|c|}{ Season } & \multirow{2}{*}{ Significance } \\
\hline & North & South & & Dormant & Growing & \\
\hline $\mathrm{Cu}$ & 169 & 93 & $* *$ & 161 & 112 & $* *$ \\
\hline $\mathrm{Zn}$ & 99 & 92 & NS & 97 & 94 & NS \\
\hline $\mathrm{Mn}$ & 15 & 12 & $*$ & 18 & 11 & $* *$ \\
\hline
\end{tabular}

The significantly higher liver $\mathrm{Cu}$-content of impala in the north is probably due to air pollution of $\mathrm{Cu}$ which could have arisen from a nearby copper smelting unit in the north (Phalaborwa) (Gummow et al., 1991). The Cucontent of the animals was significantly higher during the dormant season in comparison to the growing season. All these values were lower than those reported by Gummow et al. (1991) in the same area for cattle which died of $\mathrm{Cu}$-poisoning. According to reported values for deer, these values seem to be adequate for normal production (Puls, 1994). No significantly different values were found in the $\mathrm{Zn}$-levels between localities or seasons. It has to be kept in mind that tissue levels are not a good guide to Zn-nutrition in bovines (Puls, 1994). The Mn-levels were significantly higher in the north than in the south, as well as in the dormant season in comparison to the growing season. According to Puls (1994) the lowest liver Mn levels recorded during the growing season should be adequate for normal production of bovines.

\section{References}

Gummow, B. et al., 1991. Onderst. J. Vet. Res. 58, 33.

Puls, R., 1994. Mineral levels in animal health. $2^{\text {nd }}$ Ed. Canadian cataloguing in Publication Data, Canada.

SAS, 1985. SAS User's Guide. SAS Institute Inc., Raleigh, North Carolina. 